\title{
Overstretching solidarity? Trade unions' national perspectives on the European economic and social model
}

\author{
Marius R. Busemeyer*, Christian Kellermann** \\ Alexander Petring**** and Andrej Stuchlík****
}

\begin{abstract}
Summary
The development of a European economic and social model poses serious challenges for European trade unions. On the one hand, demand for a strengthening of the social dimension of the European integration project is growing and it is realised that this cannot be achieved by unilateral action at the national level. On the other hand, the identities and organisational capacities of trade unions are deeply embedded in national welfare state institutions, limiting the leeway for a common European social model. This article presents empirical evidence from over 100 interviews with trade union leaders and politicians from 17 EU Member States on trade unions' positions in various policy fields (economic, social and competition policies). The conclusion is that unions should reflect more critically on their embeddedness in national welfare state arrangements in order to move forward together towards the realisation of a Social Europe.
\end{abstract}

\begin{abstract}
Sommaire
Le développement d'un modèle économique et social européen pose de sérieux défis aux syndicats européens. D'une part, la demande d'un renforcement de la dimension sociale du projet d'intégration européen est en augmentation et on se rend compte qu'il est impossible de la réaliser par une action unilatérale au niveau national. D'autre part, les identités et les capacités organisationnelles des syndicats sont profondément ancrées dans les institutions nationales de l'État-providence, limitant par là la marge de manoeuvre d'un modèle social européen commun. Cet article présente des données empiriques basées sur plus de 100 entrevues avec des dirigeants syndicaux et des personnalités politiques de 17 Etats membres de l'UE sur les positions des syndicats dans divers domaines politiques (économiques, sociales et de concurrence). L'article conclut que les syndicats devraient réfléchir dans un esprit

* Max Planck Institute for the Study of Societies, Paulstr. 3, 50676 Cologne, Germany

** International Policy Analysis, Friedrich Ebert Foundation, Hiroshimastr. 17, 10785 Berlin, Germany

*** Max Planck Institute for the Study of Societies, Paulstr. 3, 50676 Cologne, Germany

**** Freie Universität Berlin, Jean Monnet Centre of Excellence, Ihnestr., 56, 14109 Berlin, Germany
\end{abstract}


plus critique sur leur ancrage dans un système national d'État-providence afin d'avancer ensemble vers la réalisation d'une Europe sociale.

\begin{abstract}
Zusammenfassung
Die Entwicklung eines europäischen Wirtschafts- und Sozialmodells stellt die europäischen Gewerkschaften vor schwierige Herausforderungen: Einerseits wächst die Erkenntnis, dass eine Stärkung der sozialen Dimension der europäischen Integration notwendig ist und dies nicht durch einseitige Aktionen auf nationaler Ebene erreicht werden kann. Andererseits sind die Identitäten und Organisationskapazitäten der Gewerkschaften tief in den nationalen Institutionen der Wohlfahrtsstaaten verankert, wodurch ihr Spielraum bei der Gestaltung eines gemeinsamen europäischen Sozialmodells eingeschränkt wird. Dieser Beitrag präsentiert empirische Ergebnisse aus mehr als 100 Gesprächen mit Gewerkschaftsführern und Politikern aus 17 EU-Mitgliedstaaten, die zu ihren Positionen in Bezug auf verschiedene Politikfelder (Wirtschafts-, Sozial- und Wettbewerbspolitik) befragt wurden. Die Autoren gelangen zu dem Schluss, dass die Gewerkschaften kritischer über ihre Verankerung in den nationalen Systemen der Wohlfahrtsstaaten nachdenken müssen, um gemeinsam auf dem Weg zu einem sozialen Europa voranzuschreiten.
\end{abstract}

Keywords: unions' policy positions, European economic and social model, worlds of welfare capitalism

\title{
Introduction
}

To proponents of the left, the current state of the European integration project exhibits a bias towards economic and against social policy matters. The creation of the European Single Market and the supranationalisation of monetary policy in the hands of the European Central Bank have not been accompanied by the establishment of a truly European social model (ESM). At the same time, union and party leaders on the national level increasingly realise that they cannot 'go it alone'. If something like a European social model is to be established, the left has to be prepared to think beyond established national welfare state models. One big obstacle on the way to a common ESM is the large heterogeneity in welfare state arrangements in EU Member States. And rather than being detached bystanders, trade unions and their identities are deeply enmeshed in these welfare state institutions (Hyman 2007; Locke and Thelen 1995). But in the end, the establishment of a strong social dimension within the European integration project cannot be achieved without truly European trade unionism (IG Metall 2007; 
Jacobi 2007). In this process of developing an ESM, if they want to be more than defenders of the status quo, national unions will eventually have to overcome or at least critically reflect upon their attachment to national welfare state legacies. In a sense, this is also an issue of trade union solidarity: the strengthening of the social dimension at the EU level might support weak unions at home, although it could go along with a redefinition of unions' roles in countries with traditionally strong unionism.

This article analyses and documents the positions of national trade unions towards a common European economic and social model. It is based on an extensive series of some 100 interviews we conducted with trade union and social democratic leaders in 17 European countries (Austria, the Czech Republic, Denmark, Finland, France, Germany, Greece, Hungary, Ireland, Italy, the Netherlands, Poland, Portugal, Slovakia, Spain, Sweden and the UK) between September 2005 and March 2006. We collected qualitative survey data on crucial policy issues of the European economic and social model $^{1}$, e.g. macroeconomic policies, social policy and cohesion, wage policy and the social dialogue. The goal of the project was to gather information about unions' positions on the national rather than the EU level, because we assumed that union representatives in Brussels could be prone to a 'pro-EU bias'. ${ }^{2}$

Bearing in mind that integrating social policy within the EU is an issue distinctly different from integrating sectors of the market economy, this article is guided by two questions: a) In which areas can we identify a single voice of unions and converging interests, and on which issues do we instead find a cacophony of positions? b) How can we explain these differences?

First, we look at delegating social policy to the supranational level from a theoretical perspective. If it is true that unions remain attached to their respective national welfare state models, we should expect a 'clustering' of unions' positions that are roughly in line with established typologies of welfare capitalism. The following theoretical section develops a framework for the analysis. Secondly, after the theoretical section, the remainder of the article presents our empirical findings grouped according to three sections: (a) economic policy, (b) social policy and (c) competition.

\section{European integration: varying preferences across welfare states}

Although not without tensions, trade unions in Europe have promoted European structures since the 1950s. Since 1973 the European Trade Union Confederation (ETUC) is

1 The policy issues are: fiscal policy and the Stability and Growth Pact, wage policy, employment policy and the Lisbon strategy, social policy, social dialogue, macroeconomic coordination, tax harmonisation, agricultural policy, structural and cohesion policy and the Services Directive.

2 Replication data, the questionnaire and more specific country information can be found here: http://www.fes.de/ipa/inhalt/ewsm.htm 
the umbrella organisation, consisting of 12 Industry Federations and 81 National Trade Union Confederations and claiming to 'speak with a single voice' on behalf of European workers and employees. ${ }^{3}$ However, neither the existence of a single voice nor the existence of the common interest of workers can be taken for granted - at least not in a European Union of 27 Member States with different levels of economic development, performances and structures. Regarding the debate on how much of a social dimension the EU should provide 4 , trade unions at the European level are primarily concerned with maintaining existing conditions (Hyman 2005: 29). Recently, many scholars have tried to define 'one' European social model (e.g. Giddens 2006) but this is not our purpose here. While most unions would probably subscribe to the proposition that sharing risks widely across society, limiting inequalities and protecting the most vulnerable are among many facets of a general definition of the ESM (Giddens 2006), we do not want to use any prescriptive definition of the ESM. Rather, we focus on what the actors themselves expect from the EU in terms of whether there is scope further to delegate national social policy competences to the EU level.

Academic research on preference formation vis-à-vis European integration has so far concentrated on voters and parties (see Marks and Steenbergen 2004; Marks et al. 2006). It is therefore necessary to think more comprehensively about concepts that can explain different and joint positions within the group of trade unions of EU Member States.

In a first step, it can be argued that European trade unions should have a common interest in defending the interests of European workers and employees. Consequently, it could be expected that trade unions show a relatively high degree of unity in positioning themselves on certain aspects of the ESM. Policies that further sustainable economic growth, full employment, the quality of the working life, or social inclusion, for instance, could be expected to be supported, while policies that favour 'upper income class interests' should be opposed.

In contrast, a more realistic understanding of trade unions and their positions vis-à-vis the ESM is to recognise that, while observing some similarities on the fundamental, more abstract, level, trade unions in European countries will differ largely with regard to their policy positions. These differences stem from various reasons: for instance, many European policies have distributional consequences (Marks 2004) that might be costly for trade unions in rich EU Member States, but beneficial for workers in poorer Member States. In practice, it will be hard to evaluate fully the distributional consequences of specific EU policies. Because of this cognitive uncertainty, it will be even harder for trade union leaders to base policy decisions on the expected distributive consequences of policies.

Instead, we hypothesise that they remain embedded in the institutional framework of the national Member States. This framework acts as a 'filter' and largely defines their identity,

3 http://www.etuc.org/r/2 [Accessed 30.01.2007].

4 E.g. the informal European Council in Hampton Court, October 2005. 
and their strategies, as well as their relation and approach to government in general (Locke and Thelen 1995). This is not to say that trade unions would willingly sacrifice the common goal of promoting the collective interests of European workers for the defence of narrowly defined national distributive interests. On the contrary, all European trade unions want to promote the social and economic advancement of their membership, but the concrete translation of membership interests into policy positions depends on the institutional and organisational environment as well as unions' identities (Hyman 2007).

Table 1 groups EU countries into five clusters largely based on established research in welfare state policy and political economy (Esping-Andersen 1990; Esping-Andersen 1999; Goodin et al. 1999; Leibfried 1992; Castles und Mitchell 1993) which capture country differences along three dimensions. Union density is a measure of how encompassing the trade union movement is in a given country. Collective bargaining coverage is often related to union density, but there are cases (e.g. France and most Mediterranean countries) with low degrees of union density, but high collective bargaining coverage. So in a way, collective bargaining coverage reflects the willingness of policy-makers to rely on the social partners in the field of economic policy. The type of welfare state (which we also use to name our country clusters) is a mostly qualitative indicator, capturing the influence of the welfare state institutional environment on identity and preference formation of unions.

Table 1: Worlds of welfare capitalism and union attributes in selected EU Member States

\begin{tabular}{|c|c|c|c|c|}
\hline Country & Welfare type & Union density & $\begin{array}{l}\text { Union } \\
\text { membership in } \\
\text { thousands (2003) }\end{array}$ & $\begin{array}{l}\text { Collective } \\
\text { bargaining } \\
\text { coverage }\end{array}$ \\
\hline Austria & \multirow{4}{*}{ Continental type } & 36.5 & $1151.0^{*}$ & 97.5 \\
\hline France & & 9.7 & 1830.0 & 92.5 \\
\hline Germany & & 25.0 & 7120.0 & 68.0 \\
\hline Netherlands & & 23.2 & 1575.2 & 82.5 \\
\hline Denmark & \multirow{3}{*}{ Scandinavian type } & 74.4 & 1710.5 & 82.5 \\
\hline Finland & & 76.2 & 1495.0 & 92.5 \\
\hline Sweden & & 81.1 & 2984.2 & 92.5 \\
\hline Ireland & \multirow{2}{*}{ Anglo-Saxon type } & 38.0 & 515.7 & n.a. \\
\hline United Kingdom & & 31.2 & 6524.0 & 32.5 \\
\hline Greece & \multirow{4}{*}{ Mediterranean type } & 27.0 & $639.0 \pm$ & n.a. \\
\hline Italy & & 34.9 & 5327.7 & 82.5 \\
\hline Spain & & 14.9 & 2196.8 & 82.5 \\
\hline Portugal & & 24.3 & $1165.0 \pm$ & 82.5 \\
\hline Czech Republic & \multirow{3}{*}{ Eastern European type } & 27.0 & $1075.2 \#$ & 27.5 \\
\hline Poland & & 14.7 & $1500.0 \#$ & 42.5 \\
\hline Slovakia & & 36.1 & 700.0 & 52.5 \\
\hline
\end{tabular}

*2002; \#2001; \pm 2003 (European industrial relations observatory on-line).

Sources: data on union membership Visser (2006: $43 \mathrm{ff}$ ), data on union density and collective bargaining coverage: $O E C D$ Employment Outlook 2004. 
The central thesis of this article is that the process of constructing a common ESM and enhancing EU social policy has different effects on different welfare states and production regimes; consequently, differences in trade unions' policy positions, which are shaped by these institutional frameworks, can be explained by their relative position in the national welfare state and labour market framework. More concretely, we consider that the continental welfare state model (in Table 1 covering among others France, Germany and the Netherlands) serves as a blueprint for a common European ESM, or, to put it differently, political leaders across Europe expect that if something like a common ESM emerged, it would strongly resemble this welfare state type. This set of countries is the 'EU core' in the sense of founding Member States which had a strong influence on the EU's social dimension in the past and still have a high share of voting power in the Council. As a consequence, trade union leaders evaluate the prospect of a common ESM against the status quo in their national setting, resulting in 'Euroscepticism' on the one hand(Scandinavia, UK) or tentative support (Mediterranean countries) on the other.

Trade unions in the 'continental' group of Member States (Germany, France, the Netherlands, Austria), have experienced a relatively long corporatist tradition, and this is especially the case in Germany, the Netherlands and Austria. Even in France, where union density is low, the collective bargaining coverage is very high. Therefore, trade unions in these countries have an interest in ongoing European integration and in creating a common standard at a high level in order to safeguard the performance of their own economic and social model. This holds true in particular when they are confronted with the competitive pressures of an increasingly heterogeneous EU. At the same time, they have only a slight interest in expanding interstate redistribution policy because as comparatively affluent Member States they would have to deliver most of the funds.

In contrast, one might expect trade unions in Anglo-Saxon as well as Scandinavian countries to be rather 'Eurosceptic'. At first sight, it seems rather odd to group AngloSaxon and Scandinavian countries in a joint country cluster. But with regard to the issue at stake here, trade unions in these countries can be expected to have similar positions. First, they have an interest in minimising interstate redistribution because these Member States are net contributors and involved in financing EU redistribution, e.g. through the European Social Fund, to a considerable extent. Secondly, and more importantly, the creation of a common ESM potentially undermines the position of trade unions in the respective national welfare state and labour market regime. Scandinavian countries have high degrees of union density, high collective bargaining coverage and a generous welfare state. Therefore, if the creation of a common ESM entails some development towards the EU average, trade unions in these countries would have to cope with some downward pressure with regard to their national social standards. At the same time, trade unions in the Scandinavian countries need at least some sort of EU policy in order to protect national arrangements from increasing competitive pressure from new EU Member States. In the UK (and to a lesser extent in 
Ireland), industrial relations are much more decentralised than in other EU countries. The imposition of a common ESM could potentially weaken the flexibility of these labour market arrangements, thus (it is perceived) weakening the competitiveness of the economy as a whole.

Trade unions in the central and eastern European Member States could be expected to have a split opinion towards the creation of a common ESM. On the one hand, as the main beneficiaries of redistribution within the EU for some time to come, trade unions in these countries will obviously welcome this type of policy. On the other hand, the economic systems of these countries, with their state-centred past and recent liberal tendencies, a comparatively low degree of decommodification, medium levels of union density and collective bargaining coverage, also testify to the fact that these countries are relatively remote from the welfare state model of the EU core. As a consequence, the establishment of a common ESM along the lines of the continental welfare state type would diminish the competitive advantage of these countries. Hence, the net gain of an interstate redistribution policy must be high enough to compensate for the benefits forfeited due to (perceived) loss of competitive advantages. Trade unions in these countries face the dilemma between on the one hand maintaining the competitive edge through low wages and liberal market arrangements and on the other striving to improve wages and social standards.

The situation is somewhat different for trade unions in the group of Mediterranean Member States. Until very recently these too benefited greatly as a result of interstate redistribution policy (structural and cohesion funds). However, they have a greater affinity to the ESM of the EU core countries. This applies to the Mediterranean Member States (Spain, Portugal, Greece) which, depending on the development of economic prosperity, manifest a medium degree of decommodification, although they have comparatively coordinated market economies. However, this also applies to Ireland, which differs from the ideal-typical Anglo-Saxon model because of the expansion of mechanisms for coordinating the market economy (for example, social pacts between employers and trade unions). In this regard, only the UK, as a representative of the Anglo-Saxon model, remains a liberal market economy within the EU. Trade unions in the Mediterranean countries can hope for improvements in the socio-political situation in their own countries as a result of the expansion of social policy at EU level and the institutionalisation of a common ESM. Because their own national welfare states and production regimes fit relatively well with the continental welfare state type, trade unions in these countries are expected to be mainly supportive of the creation of a common ESM.

In the following section we will test these theoretical propositions against our survey results. We divided the complex set of policies of the European economic and social model into three main sections: the Economy, Social policy and Competition (see Petring and Kellermann 2005). 


\section{The economy}

\section{Stability and Growth Pact/fiscal policy}

A significant majority of unions agreed that the Stability and Growth Pact (SGP) was a necessary arrangement in Europe. Nevertheless, trade unions often criticised the Pact for leaving too little room for fiscal manoeuvre in the event of weak economic growth. The $3 \%$ rule in particular was regarded as being too restrictive and as having procyclical effects. The large majority of the unions in our sample therefore favoured a general reform of the SGP criteria. The most recent relaxation of the Stability and Growth Pact in 2005 (essentially an extension of situations in which no deficit procedure was instituted despite violations of the $3 \%$ rule) was insufficient for many, since structural reform of the Pact had not been agreed. According to the majority of unions, different business cycles in Europe, to which the Pact has no answers, were an additional problem. Despite these criticisms, there was no consensus on the use of anticyclical measures at the EU level.

Most unions favoured a differentiated treatment of investments for calculating national deficits, i.e. taking into account the nature of the deficit, evaluating debts due to investment - in conformity with the Lisbon strategy - differently from debts for consumption. Another option is the abolition of the annual percentage target in favour of concentration on the $60 \%$ rule (level of indebtedness), but only a few unions were in favour of this idea. The same is true for taking into account structural budget deficits as a reference value, possibly including future pension system burdens.

Differences in trade unions' policy positions in fiscal policy across countries were relatively minor. Most union leaders expressed tentative support for EU fiscal policy arrangements, while also emphasising the need for reform. Differences in policy positions arose mainly between unions with different ideological backgrounds, i.e. the French FO was more critical and centrist unions were more supportive of the SGP. In comparison to leaders from social democratic parties, who were also interviewed as part of the project, union leaders were more critical of the provisions of the SGP (see Busemeyer et al. 2006: 148). This is because trade unions' real influence on fiscal policy is smaller than in other policy fields, therefore they can 'afford' to be more critical.

\section{Wage policy}

Currently, wage policy remains one of the most important national tools of adjustment since monetary and fiscal policy have become Europeanised. In a number of countries, unions have become involved in a new type of social pact, which aims at moderating wages (Petring and Kellermann 2005: 3). The trade unions' main goal, to prevent 'competitive disinflation', led to a productivity-growth-oriented wage policy in 1998 within the framework of the Doorn declaration (ibid.). This agreement also entails more 
far-reaching forms of coordination within the European Metalworkers' Federation, aiming to prevent wage dumping through the exchange of information and agreement on targets and to avoid inflationary tendencies by means of wage settlements (Schroeder and Weinert 2003).

However, and for different reasons, the majority of unions were against an EU-wide coordination of wage policies. In the case of wage policy, we find a clear clustering of policy positions in line with our theoretical expectations outlined above. This is also in line with Locke and Thelen (1995: 338) who argue that certain issues (and not others) can spark conflict within a given country, if the issue is connected to the "foundations on which union identities themselves rest'. Wage policy is an example of such an issue, therefore we would expect strong differences in preferences.

Not surprisingly, fierce opposition to a common EU wage policy came from Scandinavian and Anglo-Saxon countries (the 'Eurosceptics'). In the words of a Danish representative: 'This might become as flawed as the SGP. We would have rules but no instruments to make them effective.' Trade union leaders in the Scandinavian countries fear that collective wage bargaining on the EU level undermines their ability and power in national level wage bargaining, resulting in downward pressure on wages or limited flexibility to coordinate wages across economic sectors. UK trade unions, in contrast, were more concerned with maintaining the flexibility of decentralised wage bargaining, not only out of concerns for competitiveness, but also to maintain the influence of local trade unions.

In contrast, union leaders in Mediterranean countries supported stronger coordination of wage agreements. Some unions who have sceptical views on coordination were at least in favour of a stronger consultation and exchange of information. We explain the positive attitude of union representatives in Mediterranean countries by pointing to the fact that these countries are principally open towards coordination and collective wage bargaining and that EU social policy initiatives can actually help to strengthen the modestly strong position of trade unions within national arrangements.

This pattern of policy positions was corroborated when union leaders were asked about their preferred level for wage bargaining. Since the beginning of the 1990s, trade unions have changed their agenda and have moved away from their aim to develop and foster uniform wage rates in Europe (Schroeder and Weinert 2003: 577). The crucial level for wage negotiations remains national. Furthermore, at the core of such negotiations are pattern-setting collective bargaining agreements (e.g. Flächentarifverträge in Germany) and wage agreements that are generally binding. However, asked about their preferred level of agreement, some unions (one French, one Portuguese and two Greek unions) favoured EU-wide sectoral wage bargaining. One Greek trade unionist even envisaged a system with an EU-wide average of the EU- 15 with special convergence programmes for the new Member States. In contrast, union representatives interviewed in the United Kingdom preferred wage bargaining to remain at the company rather than at the national level. 
Irrespective of the level of wage negotiations, the introduction of a European minimum wage remains an issue of contention (see also Schulten et al. 2005). While there is a minimum wage in many EU countries, some trade unions regarded this as a threat to their bargaining autonomy. This is especially the case in Sweden where representatives feared minimum wages would generate an 'income policy' thereby weakening their political stance. But scope matters too: the Danish position was equally critical but a very low minimum wage is considered to be useful to help new Member States. Unions from new Member States and Mediterranean countries held the view that minimum wages should be introduced only when country-specific factors are considered. And only two Greek unions preferred a harmonised EU-wide minimum wage.

In sum, in the case of wage policy, a policy field that matters very much to all trade unions, we find clear evidence of a patterning of policy positions according to our expectations. Union leaders in Scandinavian countries were against EU-wide wage policies or collective wage bargaining at the EU level and against the imposition of a common minimum wage (or at most on a very low level out of solidarity with unions in new Member States). Trade unions in the UK were equally sceptical of a common European approach, but for different reasons. They want to maintain the flexibility of local wage bargaining. Trade unions in Mediterranean countries were most supportive, because they hope for an upward push on wages and their national institutional framework is more amenable towards coordinated solutions.

\section{Employment policy and the Lisbon strategy}

As concerns economic coordination, employment policy has been the subject of the European Employment Strategy (EES) more recently flanked by the Lisbon strategy. The mid-term revision of the Lisbon strategy has been followed by the streamlining of both procedures (European Commission 2005). The policy goals associated with employment are: reduction of unemployment, increase in employment rates, increase in women's employment rates, reduction of youth and long-term unemployment, creation of better jobs, improvement of training, extension of childcare, etc. Trade unions' positive attitude towards the Lisbon strategy was linked to support for these goals. However, many unions also criticised the strong focus on competitiveness after the modification in the course of the mid-term review in spring 2005 for being too 'neoliberal'. Most European unions assessed the impact of the EES in their countries to be rather small. The open method of coordination (OMC) is one important instrument with regard to the EES and many unions regard the OMC as a useful tool. A majority also favour an even stronger coordination of employment policies. The Scandinavian unions in our sample were opposed to this option. However, overall, we find a relatively high degree of convergence of policy positions, supporting the general goals of the Lisbon strategy, while criticising much of its actual implementation. In contrast to wage policies, this policy field is more distant and less relevant to unions' day-to-day activities in Member States. Therefore, we find a stronger convergence of policy positions, but these positions often remain at a rather abstract level. 


\section{Social policy}

\section{A common European social model?}

So far, European social policy has been mainly the subject of 'soft law', voluntary coordination, selective regulation or court decisions. But more recently, demands for strengthening the 'social dimension' of European integration have become stronger. All of our interviewees agreed with the general statement that it is necessary to strengthen the social policy perspective of the European economic model, which is often perceived as 'neoliberal' and to the left of the political spectrum. Therefore, our evidence from interviews suggests that there is a clearly perceived need to strengthen 'the social dimension', however defined.

On the other hand, comparative welfare state research has shown that differences between national models continue to persist and that no convergence of welfare states towards a European social model can be discerned over the 1990s (e.g. Petring 2006). Consequently, and despite the commonly perceived need for a stronger social dimension, the heterogeneity of welfare states is also viewed as the major obstacle to a stronger EU social policy, as most unions in the sample reported. This holds true even for the new Member States: all of them agree with the aim to 'strengthen the social dimension' but at the same time conclude that due to the EU's enlargement in 2004, this aim has become increasingly unrealistic (e.g. one Slovak representative). The majority of interviewees even rejected straightaway the idea of a single social model in Europe. ${ }^{5}$ Opposition to that idea came mainly from Scandinavian but - and that is more surprising - also from continental and Mediterranean unions. Five unions in our sample expressed the view that a single social model was not only unrealistic, but also not desirable. Moreover, they considered the European social model to be more of a concept than a vital political agenda. In this perspective, unions should rather try to influence the translation of EU social policy directives and standards into national law. The scepticism with regard to the establishment of a common ESM shows that unions and their identities are deeply embedded in national welfare state arrangements. This reflects the general dilemma of European trade unions, and maybe the European left in general: on the one hand, there is a strong desire to strengthen the welfare state dimension of the EU; on the other, political leaders have not yet found a way to solve institutional conflicts between different welfare states and production regimes.

As a consequence of this general dilemma, political leaders in our survey tended to consider the open method of coordination (OMC) as a panacea, because it provides some (soft) coordination of policies, but basically has no immediate consequences for national policy-making. This is an interesting finding which is rather opposed to the rapidly growing academic attention devoted to the OMC (e.g. Daly 2006; O'Connor 2005; Zeitlin et al. 2005). Though unionists did consider the OMC to be a useful tool

5 Question: 'Is there a single European social model to be aimed at and what should it look like?' 
for social policy, they overwhelmingly found it to have very little impact on the domestic arena. In this respect, it may be telling that most interviewees also exhibited a supportive view on the OMC, because it allows union leaders to demonstrate they are 'doing something', thus side-stepping more serious conflicts which would inevitably result from a more far-reaching Europeanisation of social policies.

\section{The social dialogue}

'Dialogue with the social partners is one of the pillars of the European social model, although freedom of association and wage bargaining autonomy are still the prerogative of Member States' (Petring and Kellermann 2005: 6). The Commission can 'develop the dialogue between the social partners at the European level, which could, if the two sides consider it desirable, lead to relations based on agreement' (Article 138 of the EC Treaty). Alongside social dialogue at the macro level of the EU, 31 sectoral social dialogue committees have been set up in the EU since 1998. Following formal EU recognition of the social partners' right to negotiate framework agreements at European level, they have signed three cross-sectoral European framework agreements, which have been implemented as Directives: on parental leave (1996), part-time work (1997) and fixed-term contracts (1999). Trade unions and employers implemented further Europeanlevel deals under the system of 'autonomous' social dialogue, covering conditions for teleworkers (2002), lifelong learning (2002) and work-related stress (2004).

Further results of sectoral social dialogues have the status of non-legally-binding common standpoints and declarations. The reason for the low output of this form of regulation is above all the interest of the employers' organisations in maintaining the status quo. Because there must be a consensus of the social partners for starting negotiations, UNICE and CEEP possess a de facto veto right (Schroeder and Weinert 2003: 572).

As a central institution of the European social model, the social dialogue is generally viewed positively by the unions in our sample. In addition, the general idea of a social dialogue, i.e. policy coordination in corporatist institutions, is largely supported. Therefore, almost all unions called for a stronger role for the social partners in EU policy-making in general.

However the picture was more mixed when union leaders were asked for an assessment of actual results of the dialogue so far. Positive and negative assessments are in a balance here: while a majority of Scandinavian and Mediterranean unions in the survey were not satisfied with the results of social dialogue, a contrasting picture emerged from the Anglo-Saxon and continental countries. Unions in eastern Europe in particular exhibited a positive assessment of the results of the EU social dialogue. In general, however, trade union leaders were more sceptical than leaders of social democratic parties. For the latter, the social dialogue seems to be more of a political tool to reach out to labour and business, while social partners - and trade unions in particular expect real results from negotiations. 
Consequently, unions mostly agreed on identifying the most pressing problem in the establishment of a working social dialogue: the cooperation and participation of employers as well as the inability or unwillingness of the European Commission to enforce the employers' commitment. As one Danish interview partner observed, employers' associations also lack the organisational capacity to enforce jointly decided policies on the national level. Some union leaders (e.g. in Spain and Greece) explicitly criticised the European Commission for not doing enough to promote the social dialogue and for using the employers' opposition as an 'excuse for doing nothing'.

More serious differences in opinion arose when unions were asked how to strengthen the role of social partners. A majority of respondents supported a strengthening of the role of the Commission, which on this view is supposed explicitly to delegate policymaking responsibilities to the social partners and to put more pressure on employers. A minority of unions, predominantly those with syndicalist traditions and a strong organisational base, were against strengthening the role of the Commission: in their view, the union movement should strengthen its position by its own actions. Here, again, we see how unions' self-perceptions, identities and organisational capacities have an impact on their preference formation. Strong unions with a syndicalist tradition (e.g. the French FO) reject state support in the organisation of employees' interests, while weaker unions look to state actors in order to obtain organisational support.

In sum, concerning the social dialogue, we also find evidence for a clustering of trade unions' policy positions along the lines suggested in the theoretical section. On an abstract level, policy positions on the need for an extended social dialogue were relatively convergent and coherent. But when asked about how to achieve this goal, policy positions start to diverge and largely reflect the relative position of the respective union within the national institutional framework. Strong unions are less supportive of following the 'supranational' route by further institutionalising the role of social partners on the EU level and using the Commission to increase pressure on employers. Unions from countries with strong traditions of social partnership emphasise that the process of European integration must not endanger the internal workings and integrity of national institutions, while, at the same time, touting social partnership as an effective policy instrument to be used more extensively at national level (e.g. in Austria). In contrast, countries with weak traditions of social partnership (e.g. Greece) were more supportive of strengthening the EU level, because they opined this would also strengthen their role within the national settings.

\section{European Works Councils}

One important element in unions' efforts to strengthen the social dialogue at the European level is the long overdue revision of the European Works Council Directive ${ }^{6}$

6 Council Directive 94/45/EC of 22 September 1994 'on the establishment of a European Works Council or a procedure in Community-scale undertakings and Community-scale groups of undertakings for the purposes of informing and consulting employees'. 
(ETUC 2005) adopted in 1994 to promote social dialogue at the enterprise level. European Works Councils (EWCs), which are primarily designed for information and consultation, have so far been established in approximately $40 \%$ of enterprises which fall under the scope of the Directive (Lecher and Platzer 2003). In consultation with the trade unions, European Works Councils can make an important contribution to transnational coordination. Of course, the wholesale Europeanisation of wage policy is still regarded by many with scepticism (see above). However, European Works Councils could play an important role for Europe-wide sectoral collective agreements. A strongly perceived weakness of the current Directive is the lack of a formal recognition of the role of trade unions (ETUC 2005). Not surprisingly, most unions in our sample were strongly in favour of strengthening the links between trade unions and works councils. In particular, a revised European Works Council Directive could and should help to strengthen sectoral social dialogues at EU level, as one French trade unionist remarked. Overall, unions agreed that the institution of European Works Councils can buttress the development of European trade unionism.

\section{Competition}

\section{Tax competition}

Tax policy of the European Union so far relates predominantly to the rates of indirect taxes (such as VAT and consumption taxes) as part of the European Single Market programme (Petring and Kellermann 2005: 8). Apart from that, tax provisions must not hinder free movement of capital within the Community. Indeed, cross-border competition in corporate taxation has intensified after eastward enlargement brought into the EU a new swathe of low-tax Member States (e.g. Estonia, Slovakia). In the long run, pressure to lower tax rates in high-tax countries will continue to increase (Jarass and Obermair 2005). As a consequence, there has been a proposition to introduce a compulsory common consolidated tax base in combination with a minimum tax rate at the EU level. So far, the EU has only achieved the enactment of a 'code of behaviour' which is supposed to ensure that no competition-distorting tax benefits are introduced (Kellermann et al. 2007). The EU is not aiming at the development of uniform tax rates or minimum tax rates, although the Commission plans to propose a non-compulsory common corporation tax base.

The phenomenon of tax competition, predominantly in corporate taxation, was also seen as an important issue by a large majority of unions in our sample: most interviewees agreed that tax competition in the EU is in fact happening and that it is 'harmful'. Furthermore, they agreed that tax competition has intensified in the wake of enlargement. 'Enlargement aggravates the problem because the new Member States possess a very lean (and liberal) state, despite their communist past', said a French unionist. 
The introduction of a European minimum tax rate for companies is also strongly supported by the unions in our sample. Most support came from unions in Mediterranean countries, but there is no significant regional pattern within the group of unions who are against this proposal.

In order to accelerate integration of the single market the EU has taken a number of measures to coordinate and adapt taxation systems. The requirement of unanimity in the Council of Ministers has in this respect once more proved a hindrance. Tax policy is therefore resisting the trend towards an ever closer union (Genschel 2002). Most unions in our sample support the idea of adopting majority voting instead of the principle of unanimity in the Council of Ministers. This stands in contrast to the positions held by social democratic parties (Busemeyer et al. 2006: 151), which are much more divided on this issue - with social democrats from Scandinavia most opposed and party leaders from eastern Europe most in favour. An explanation for the difference in positions between union leaders and social democrats lies - as in the case of fiscal policy - in the fact that the issue of tax policy is less relevant for unions than other policy areas.

\section{Conclusion}

There are a number of interesting findings concerning trade unions' positions from our survey in the enlarged European Union of 27 Member States. Table 2 presents a summary of trade unions' positions in the respective policy areas. We distinguish between the general perception of a given problem and actual policy proposals. It can be seen that there is a relatively high degree of agreement in the policy positions of European trade unions on general issues on an abstract level as well as on issues that either affect European workers in different countries similarly (e.g. European Works Councils) or on which trade unions have a relatively low influence (e.g. monetary and fiscal policies). On a very general level, trade unions were supportive of the promotion of the social dialogue and the strengthening of the social dimension, but without being able to formulate more concrete proposals. Hence, the lower the level of abstractness, the stronger is the diversity of union positions. In addition, it is telling that unions seem to find it easier to come to agreement on issues to oppose (e.g. ruinous tax competition and social dumping) than on constructive proposals to establish a common ESM.

The largest divergence of policy positions was observed with regard to those issues that are crucial to the unions' day-to-day activities. We find considerable evidence for the clustering of policy positions according to the country groupings outlined in the theoretical section, reflecting differences in union identities and embeddedness in national welfare state arrangements. For example, we found only partial agreement on specific initiatives in the area of social policy. While most unions agree with the use of the OMC to develop a stronger social dimension, there is no consensus on further and specific measures. Equally, positions on the minimum wage vary significantly and cluster according to the five welfare types: Mediterranean and eastern European unions 
support the introduction of a minimum wage, while Scandinavian unions in particular oppose such a policy. Obviously, Scandinavian countries with their encompassing unions and universal welfare systems associate this idea with a deconstruction of their collective bargaining system.

Table 2: Trade union positions with regard to the European ESM

\begin{tabular}{|l|l|l|l|l|l|l|}
\hline & Fiscal policy & $\begin{array}{l}\text { Monetary } \\
\text { policy }\end{array}$ & Wage policy & $\begin{array}{l}\text { Macroeconomic } \\
\text { coordination }\end{array}$ & Social policy & $\begin{array}{l}\text { Tax } \\
\text { competition }\end{array}$ \\
\hline $\begin{array}{l}\text { General } \\
\text { perceptions }\end{array}$ & $\begin{array}{l}\text { Consensus: } \\
\text { SGP necessary, } \\
\text { but reform of } \\
\text { SGP criteria } \\
\text { also required } \\
\text { monport for } \\
\text { union }\end{array}$ & $\begin{array}{l}\text { Consensus: } \\
\text { suprys: }\end{array}$ & $\begin{array}{l}\text { Consensus: } \\
\text { wust dumping } \\
\text { prevented }\end{array}$ & $\begin{array}{l}\text { Consensus: } \\
\text { macroeconomic } \\
\text { coordination is } \\
\text { necessary }\end{array}$ & $\begin{array}{l}\text { Consensus: } \\
\text { stronger social } \\
\text { dimension } \\
\text { preferable; } \\
\text { 'Social policy } \\
\text { tourism' is not } \\
\text { a problem }\end{array}$ & $\begin{array}{l}\text { Consensus: tax } \\
\text { competition } \\
\text { must be } \\
\text { prevented }\end{array}$ \\
\hline $\begin{array}{l}\text { Policy } \\
\text { proposals }\end{array}$ & $\begin{array}{l}\text { Medium level } \\
\text { of support: } \\
\text { take public } \\
\text { investments } \\
\text { into account } \\
\text { when } \\
\text { calculating } \\
\text { deficits }\end{array}$ & $\begin{array}{l}\text { Consensus: } \\
\text { ECB should } \\
\text { place a } \\
\text { stronger focus } \\
\text { on growth and } \\
\text { employment }\end{array}$ & $\begin{array}{l}\text { No consensus } \\
\text { on introduction } \\
\text { of EU } \\
\text { minimum } \\
\text { wage; } \\
\text { No consensus } \\
\text { on EU-wide } \\
\text { coordination of } \\
\text { wage } \\
\text { bargaining }\end{array}$ & $\begin{array}{l}\text { No concrete } \\
\text { proposals }\end{array}$ & $\begin{array}{l}\text { No consensus } \\
\text { on a common } \\
\text { European } \\
\text { social model; } \\
\text { Tentative } \\
\text { consensus on } \\
\text { using OMC } \\
\text { instead }\end{array}$ & $\begin{array}{l}\text { Tentative } \\
\text { consensus on } \\
\text { introduction of } \\
\text { EU minimum } \\
\text { taxation and } \\
\text { majority voting } \\
\text { in the Council } \\
\text { on tax issues }\end{array}$ \\
\hline
\end{tabular}

All in all, the findings presented in this paper show that European trade unions find themselves in a serious dilemma. On the one hand, there is a clear and strong demand for a strengthening of the social dimension of the European integration project. Trade unions have by and large realised that a stronger Social Europe cannot be achieved through unilateral or isolated action on the national level, as the economic and social interdependence between Member States has become too far-reaching. On the other hand, trade unions remain very much embedded in their respective national institutional arrangements. This is not just an issue of power and influence, but also of identity. The heterogeneity of social models in the Member States of the European Union therefore remains a serious obstacle towards the establishment of a common European social model.

At the same time, when unions face the challenges of Europeanisation, their position and influence 'at home' is also put under pressure. As Hyman (2007: 196) observes, diversity in trade unions' organisational and political capacities across countries will probably increase as a result of internationalisation, because powerful and encompassing unions are better able to maintain their influence than weaker ones. In terms of strategy and trade union solidarity, the real challenge for unions is therefore to realise that 'Social' Europe can only be created by means of transnational cooperation and that this cooperation can only be achieved when unions acknowledge and critically reflect upon their continued embeddedness in national welfare state regimes. In line 
with Hyman's (2007: 204) appeal to trade union members to 'perceive common interests despite difference', trade unions have to reach out to their allies in other Member States to create a truly European trade union movement.

\section{References}

Abelshauser, W. (2006) 'Der wahre Wert der Mitbestimmung', Die ZEIT, 21 September, 28.

Arestis, P. and W. Mosler (2005) 'Makroökonomische Politik im Euroraum: Eine kritische Betrachtung', WSI-Mitteilungen, 12/2005.

Busemeyer, M. R., C. Kellermann, A. Petring and A. Stuchlik (2006) 'Europäische Verteilungskonflikte und sozialdemokratische Positionen zum Europäischen Wirtschafts- und Sozialmodell', IPG - Internationale Politik und Gesellschaft, 4, 138-156.

Castles, F. G. and D. Mitchell (1993) 'Worlds of Welfare and Families of Nations', in F. G. Castles (ed.) Families of nations. Patterns of public policy in Western democracies, Aldershot: Dartmouth, 93-128.

Daly, M. (2006) 'EU Social Policy after Lisbon', Joumal of Common Market Studies, 44 (3), 461-481.

Esping Andersen, G. (1990) The three worlds of welfare capitalism, Cambridge: Polity Press.

Esping-Andersen, G. (1999) Social Foundations of Postindustrial Economies, Oxford: Oxford University Press.

ETUC (2005) 'ETUC strategy in view of the revision of the European Works Councils Directive'. www.etuc.org/a/578?var recherche=european\%20works $\% 20$ council $\% 20$.

European Commission (2005) Communication to the Spring European Council, Working together for growth and jobs. A new start for the Lisbon Strategy, $\operatorname{COM}(2005) 24$ final, 2 February 2005, Brussels.

Giddens, A. (2006) Europe in the Global Age, London: Polity Press.

Goodin, R. E., B. Headey, R. Muffels and H.-J. Dirven (1999) The Real Worlds of Welfare Capitalism, Cambridge: Cambridge University Press.

Hyman, R. (2005) 'Trade Unions and the Politics of the European Social Model', Economic and Industrial Democracy, 26 (1), 9-40.

Hyman, R. (2007) 'How can trade unions act strategically?', Transfer, 13 (2), 193-210.

IG Metall (2007) 'Für ein solidarisch erneuertes Europa: Ein europapolitisches Memorandum der IG Metall', Vorstand der IG Metall, Frankfurt a.M.

Jacobi, O. (2007) 'Europäisch erneuerte Gewerkschaften', presentation at the 8th International Conference of the Otto Brenner Stiftung 'Ein soziales Europa im globalen Wettbewerb', Budapest 2007.

Jarass, L. and G. Obermair (2005) Vorschlag für ein zukünftiges EU-Steuersystem, mimeo.

Kellermann, C., T. Rixen and S. Uhl (2007) 'Europeanizing Corporate Taxation to Regain National Tax Policy Autonomy', Friedrich Ebert Stiftung, International Policy Analysis, July 2007. 
Kittel, B. (2002) 'EMU, EU Enlargement, and the European Social Model: Trends, Challenges, and Questions', MPIfG Working Paper No 02/1.

Kvist, J. (2004) 'Does EU enlargement start a race to the bottom? Strategic interaction among EU member states in social policy', Journal of European Social Policy, 14 (3), 301-318.

Lecher, W. and H.-W. Platzer (2003) 'Europäische Betriebsräte', in W. Schroeder and B. Weßels (eds.) Die Gewerkschaften in Politik und Gesellschaft der Bundesrepublik Deutschland, Wiesbaden: Westdeutscher Verlag, 588-613.

Leibfried, S. (1992) 'Towards a European Welfare State? On Integrating Poverty Regimes into the European Community', in Z. Ferge and J. E. Kolberg (eds.) Social Policy in a Changing Europe, Frankfurt a.M./Boulder: Campus/Westview Press, 245279.

Locke, R. M. and K. Thelen (1995) 'Apples and Oranges Revisited: Contextualized Comparisons and the Study of Comparative Labor Politics', Politics and Society, 23 (3), 337-367.

Marks, G. (2004) 'Conclusion: European integration and political conflict', in G. Marks and M. Steenbergen (eds.) European Integration and Political Conflict, Cambridge: Cambridge University Press, 235-259.

Marks, G. and M. Steenbergen (eds.) (2004) European Integration and Political Conflict, Cambridge: Cambridge University Press.

Marks, G., L. Hooghe, M. Nelson and E. Edwards (2006) 'Party Competition and European Integration in the East and West', Comparative Political Studies, 39 (2), 155-175.

O'Connor, J. (2005) 'Policy coordination, social indicators, and the social policy agenda in the European Union', Journal of European Social Policy, 15 (4), 345-361.

Petring, A. (2006) 'New Labour im Vergleich. Konvergenz oder Divergenz in der europäischen Sozialdemokratie?', in S. Berg and A. Kaiser (eds.) New Labour und die Modernisierung Großbritanniens, Augsburg: Wißner, 301-337.

Petring, A. and C. Kellermann (2005) 'New Options for a European Economic and Social Policy', Friedrich-Ebert Foundation, Europäische Politik, October.

Scharpf, F. W. (2000) Akteurszentrierter Institutionalismus, Opladen: Leske+Budrich.

Schroeder, W. and R. Weinert (2003) 'Europäische Tarifpolitik: Ein neues Politikfeld?', in W. Schroeder and B. Weßels (eds.) Die Gewerkschaften in Politik und Gesellschaft der Bundesrepublik Deutschland: Ein Handbuch, Wiesbaden: Westdeutscher Verlag, 567-589.

Schulten, T., C. Schäfer, R. Bispinck, A. Rieger, B. Ringger, H. Baumann, M. Husson and A. Math (2005) 'Thesen für eine europäische Mindestlohnpolitik', HansBöckler-Stiftung, Düsseldorf/ Zürich/Paris, 15 April. http://www.boeckler.de/pdf/ wsi 2005 thesen mindlohn de.pdf

Visser, J. (2006) 'Union membership statistics in 24 countries', Monthly Labor Review, January, 38-49.

Zeitlin, J., P. Pochet and L. Magnusson (eds.) (2005) The Open Method of Coordination in Action. The European Employment and Social Inclusion Strategies, Brussels: P.I.E.Peter Lang. 